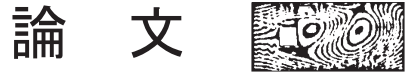

\section{種々の加撃体を用いた合わせガラスの耐衝撃試験と標準加撃体の提案 Missile Impact Resistant Test for Laminated Glasses using Various Missiles and a Proposal of Standard Missiles}

\author{
丸山 敬 ${ }^{* 1}$ \\ 河井宏允 ${ }^{* 2}$ \\ 西村宏昭 $* 3$ \\ 花谷真由子 ${ }^{* 4}$ \\ Takashi MARUYAMA, Hiromasa KAWAI, Hiroaki NISHIMURA, Mayuko HANATANI
}

\section{SUMMARY}

\begin{abstract}
Even though the importance of protecting windows from windborne debris under strong winds, there are still no available building codes or standards for their protection to building cladding in Japan. By contrast, some specifications for cladding performance under impact from windborne debris, including testing methods, exist in some foreign country and ISO standards. It is necessary to investigate the impact performance for roof tiles, representative windborne debris in Japan, in order to make domestic codes or standards. We made a new designed air cannon which can propel not only steel balls and a lumber but also a roof tile as missile. A series of impact tests based on ISO 16932 was conducted on laminated glasses by various missiles. This paper described the results of the impact performance and proposed standard missiles those include a lumber missile with equivalent destructive power to roof tiles.
\end{abstract}

key words : impact resistant test, laminated glass, roof tile, windborne debris, strong wind disaster, standard missiles, ISO 16932

\section{1. はじめに}

我々のグループでは強風時の飛散物による建築物

の被害の防止，低減にむけて，空ガラスの耐衝撃破壊

性状を調べている。文献 1,2 では, 飛散物に対するガ

ラスの耐衝撃破壊性状を明らかにするため, 国際標準
ISO 16932)（以降“ISO 規格”と記述する）に従った試験 を行うことのできる装置を製作して，普通フロートガ ラス, 強化ガラス, 網入りガラス, フィルム貼りガラ スの破壞性状を調べ, ISO 規格による評価判定を行っ た。その結果, フィルム貼りガラスでガラス厚 $5,6 \mathrm{~mm}$,

\footnotetext{
* 1 京都大学防災研究所 教授

Professor, Disaster Prevention Research Institute, Kyoto University

*2 東京電機大学理工学部 客員教授

Guest Professor, Tokyo Denki University

*3（一財） 日本建築総合試験所 試験研究センター環境部・耐風試験室長

Head Researcher, General Building Research Corporation of Japan

*4 京都大学 大学院生

Graduate Student, Kyoto University

（原稿受理年月日：2013 年 10 月 5 日，採用決定 : 2013 年 12 月 2 日）
} 
フィルム厚 $350 \mu \mathrm{m}$ 以上で ISO 規格の鋼球を用いた加 撃体に対して合格となったが，他のガラスでは ISO 規 格を合格したものはなく, これらのガラスが飛散物に 脆弱であることが明らかとなった。また，網入りガラ ス，フィルム貼りガラスでは亀裂が全体に広がらず, あるいは, 亀裂が広がっても破片が飛び散らないこと や，強化ガラスでは細かな破片に割れる破壞性状は， けがを引き起こすようなガラス片の減少につながり, 人的被害の低減に有用であることを示した。本報では これらのガラスに引き続き, より耐衝撃性能の高い合 わせガラスについて ISO 規格に従った試験を行い, 而 衝撃破壞性状を調べるとともに, ISO 規格などで採用 されている加撃体に加えて, 日本における飛散物の代 表として瓦を取り上げ，日本における台風の強風によ るガラスの耐衝撃試験および性能評価方法の提案に 向けた基礎資料を得ることを目的として行った実験 結果を報告する。

日本における建築物の耐風設計の基本となってい る建築基準法(2011) $)^{4)}$, 同施行令 $(2012)^{5)}$, 建設省告示 $\left.(2000,2007)^{6}\right)$ や建築物荷重指針・同解説 $\left.(2004)^{7}\right)$ は強風 による建築物や建築部材の耐風圧性能を規定してい るだけで, 強風時の飛来物による耐衝撃性能は要求し ておらず，その評価方法や基準，ガイドラインも存在 しないのが現状である。そのため, 而衝撃試験および 性能評価方法の策定が急務となっているが，策定にあ たっては日本における飛散物被害の現状を反映する だけでなく，ISO 規格など諸外国の試験・性能評価方 法との整合性を取ることが重要となる。そこで本報で は, 耐衝撃性能の高い合わせガラスを試験体として行 った ISO 規格に従った試験に加えて, 加撃体として瓦 を発射することのできる装置を開発し、瓦を用いた耐 衝撃試験の結果をもとに, 諸外国の耐衝撃試験および 耐衝撃性能評価方法を参考にしながら, 日本における 而衝撃試験用の標準加撃体の提案を行う。

\section{2. 而衝撃試験および性能評価方法}

2.1 飛散物を発生させる強風の種類と要求される而 衝撃性能

日本において飛散物を発生させる主な強風事象に は台風と竜巻がある。竜巻は, 規模は小さいが気圧低 下を伴った極めて強い風によって多くの飛散物を発 生させる。一方, 台風は竜巻に比べてはるかに規模が 大きく, 広範囲かつ長時間にわたって強風が吹くこと から，飛散物よる被害の総量は多大なものとなる。風
圧によって破壊された建物などの一部は飛散物となっ て被害を広げるが, 多くの建築物外装材は飛散物の衝 撃を受けて無傷のままであることは少なく，何らかの ダメージを受ける。外装材の耐衝撃性能を考える場合, 耐風性能を含む建築物の性能に大きな影響を及ぼさな い飛散物の衝突による凹みや亀裂，小さな開口などの 軽微なダメージは許容できるとしても, 雨や風が建築 物の室内に浸入し, 室内の圧力上昇から屋根を飛ばす など，室内居住者への安全を脅か寸重大な被害に発展 するような大きい開口の発生は防がなければならない。 また, 台風の場合は強風の継続時間が長いため, その 間に被害が進展しないことも必要となる。

\section{2 既存の試験・評価方法}

飛散物の衝撃の強さは飛散物の質量と衝突速度の関 数で表すことができるが，それに耐える建築物外装材 の性能は，飛散物之外装材の両方の剛性や硬さ等の材 料特性や形状，サイズなど多くの要因に依存するため に，解析的に明らかにすることが困難な場合が多い。 そのため, 飛散物に対する耐衝撃性能は飛散物を模擬 した加撃体を試験体に衝突させて生じる損傷が，所定 の規準を満たすことで確認する方法が提案され，その ための試験方法と評価基準が開発され用いられてきた。

耐衝撃試験用の加撃体が初めて登場したのは, 1974 年にオーストラリア北部のダーウィン市を襲ったサイ クロン・トレーシーの飛散物による被害の教訓からで あり, ダーウィン地区建築マニュアルの 1976 年建築基 準に $2 \times 4$ 木片を用いることが規定された ${ }^{8)}$ 。アメリカ 合衆国では 1992 年のハリケーン・アンドリューによる 飛散物被害調査の後, フロリダ州 Dade 郡建築基準委員 会が南フロリダ建築基準の試験用加撃体として $2 \times 4$ 木片を採用した ${ }^{9)}$ 。このとき, 最初は屋根瓦を加撃体 として選んだが, 瓦には種類が多いため, 標準加撃体 の選定と試験の再現性の確保が困難であるという理由 から $2 \times 4$ 木片となった経緯がある ${ }^{10)}$ 。

その後, 試験方法, 対象部位, 加撃体の種類などが 規定され, 現行のフロリダ建築基準 ${ }^{11)}$ では建築物の開 口を防御する部材の試験方法と而衝撃性能の評価方法 が示されている。加撃体は対象となる部位の設置高さ により選択され，高いところには小石などの軽くて小 さな飛散物が高速で衝突するとして, $2 \times 4$ 木片だけで なく鋼球も規定されるようになった。また, 八リケー ンによる強風を想定し, 衝撃試験に合格した後, 繰り 返し圧力載荷を受けても, 試験体が取付け枠から脱落 せず, 規定の亀裂や開口が生じないことが求められた。 
アメリカ合衆国では八リケーンだけでなく竜巻に よる強風災害も数多く発生しており, 竜巻による飛散 物に対する指針も策定されている。合衆国連邦緊急管 理局標準 FEMA P-361 ${ }^{12}$ は避難者の安全を確保する ための公共避難所の設計施工ガイダンスで, ハリケー ンだけでなく竜巻も対象としている。試験に用いられ る加撃体として $2 \times 4$ 木片が採用され, 鉛直部材に対 する水平加撃だけでなく, 屋根や天井などの水平部材 に対する鉛直加撃も規定されている。ただし，このガ イダンスは竜巻に対するものなので, 加撃体による衝 撃試験後の繰り返し圧力載荷は要求されていない。

飛散物に対して要求される防御性能については, 対 象となる建物, 構造物の用途や重要度によって分類さ れる。例えば, 合衆国エネルギー局が提供する DOE-STD-1020 $0^{13)}$ では，当局が管轄する施設の自然八 ザードに対する設計と評価のために, 構造物, システ ムおよび材料を 4 つ性能カテゴリーに分類している。 性能カテゴリー1 1 ASCE $7^{14)}$ の建築物カテゴリーII の 通常建築物, 性能カテゴリー2 は ASCE 7 の建築物カ テゴリーIVの重要施設に相当し, ともにハリケーン時 の強風のみを対象とする。性能カテゴリー3 と 4 は, 原子力発電所やそれらの付带施設に要求され, ハリケ ーンと竜巻を対象としたより高い安全性が求められ, 外装材の完全性は要求されないが, 破損・脱落は許容 されない。さらに, ISO 169323)では, 次節で紹介する ASTM に準じて, 「建築物のガラス一破壊的暴風に耐 える安全ガラスー試験と分類」が示されている。以下 ではそれらを比較しつつ, ガラスの耐衝撃試験および 性能評価方法を考察する。

なお, 日本における既存の耐衝撃性能の評価方法と しては, JIS（日本工業規格）により合わせガラスに 対して、落球試験, ショットバック試験による評価方 法が規定されている ${ }^{15)}$ が，この二つの試験法は運搬 時の衝撃や人体等の衝突による衝撃を対象としてい る。したがって, 本研究で扱う台風時の強風による飛 来物のように, 高速で衝突する物体を想定したもので はない 16)。

\subsection{ASTM および ISO 規格}

ASCE $7^{14)}$ には, ハリケーンを対象とした飛散物の衝 突による外装材の性能基準が定められている。ハリケ ーン発生地域内の基本風速は高さ $10 \mathrm{~m}$ における 3 秒ガ ス卜風速で表される基本風速が $110 \mathrm{mph}(49.2 \mathrm{~m} / \mathrm{s})$ 以 上で海岸線から 1 マイル以内の地域と八ワイ, および 基本風速が $120 \mathrm{mph}(53.6 \mathrm{~m} / \mathrm{s})$ 以上の地域は飛散物発
生地域と定義され,「飛散物発生地域内にある建築物の 外装材は ASTM E1996-04 ${ }^{17)}$ の性能基準を満たす耐衝撃 性能を有するか, または耐衝撃カバーで防御しなけれ ばならない」としている。ASTM E1996-04 は「ハリケ ーンによる飛散物が衝突する屋外空, カーテンウォー ル, ドア，および衝撃防御システムの性能における標 準仕様書」で, 試験方法の詳細は ASTM E1886-04 ${ }^{18)}$ で 決められている。ISO 規格は板ガラスを対象とした試 験標準で，その仕様と試験方法は ASTM E1886-04 と E1996-04 に準じている (以降 ASTM E1886-04 と E1996-04 “ASTM 規格”と記述する)。以下では, ASTM 規格と ISO 規格を比較しつつ，ガラスの耐衝撃 試験および性能評価方法を考察する。

1）加撃体の種類

加撃体の種類は ASTM, ISO 規格ともに表 1, 2 に示 す 5 種類で, 建物の建設地が含まれる強風ゾーン, 防 御レベル，および試験対象となる部材が設置される地 上高さによって, 試験に用いる加撃体が選ばれる。加 撃体の種類は小石などの小片を模擬した鋼球と, それ より大きな飛来物を模擬した木片が示されている。木 片については質量, 衝突速度ともにほぼ同じ加撃体が 用いられるが，ASTM では衝撃の小さな加撃体 B が採

表 1 加撃体の種類（ASTM E 1996-04） Table 1 Missile types and impact speed (ASTM E 1996-04)

\begin{tabular}{|c|c|c|}
\hline 名称 & $\begin{array}{c}\text { 質量 (誤差), 材質, } \\
\text { 長さ (誤差) }\end{array}$ & 衝突速度 (誤差) \\
\hline A & $2 \mathrm{~g}( \pm 0.1 \mathrm{~g}) /$ 個，鋼球 10 個 & $39.62 \mathrm{~m} / \mathrm{s}( \pm 1 \%)$ \\
\hline B & $\begin{array}{c}0.91 \mathrm{~kg}( \pm 0.1 \mathrm{~kg}), 2 \times 4 \text { 木片, } \\
0.525 \mathrm{~m}( \pm 0.1 \mathrm{~m})\end{array}$ & $15.25 \mathrm{~m} / \mathrm{s}( \pm 2 \%)$ \\
\hline $\mathrm{C}$ & $\begin{array}{c}2.05 \mathrm{~kg}( \pm 0.1 \mathrm{~kg}), 2 \times 4 \text { 木片, } \\
1.2 \mathrm{~m}( \pm 0.1 \mathrm{~m})\end{array}$ & $12.19 \mathrm{~m} / \mathrm{s}( \pm 2 \%)$ \\
\hline $\mathrm{D}$ & $\begin{array}{c}4.1 \mathrm{~kg}( \pm 0.1 \mathrm{~kg}), 2 \times 4 \text { 木片, } \\
2.4 \mathrm{~m}( \pm 0.1 \mathrm{~m})\end{array}$ & $15.25 \mathrm{~m} / \mathrm{s}( \pm 2 \%)$ \\
\hline $\mathrm{E}$ & $\begin{array}{c}4.1 \mathrm{~kg}( \pm 0.1 \mathrm{~kg}), 2 \times 4 \text { 木片, } \\
2.4 \mathrm{~m}( \pm 0.1 \mathrm{~m})\end{array}$ & $24.38 \mathrm{~m} / \mathrm{s}( \pm 1 \%)$ \\
\hline
\end{tabular}

表 2 加撃体の種類（ISO 16932）

Table 2 Missile types and impact speed (ISO 16932)

\begin{tabular}{|c|c|c|}
\hline 名称 & 質量 (誤差), 材質 & 衝突速度 (誤差) \\
\hline $\mathrm{a}$ & $2 \mathrm{~g}( \pm 0.1 \mathrm{~g}) /$ 個, 鋼球 10 個 & $39.7 \mathrm{~m} / \mathrm{s}( \pm 1 \%)$ \\
\hline b & $2.05 \mathrm{~kg}( \pm 0.1 \mathrm{~kg}), 2 \times 4$ 木片 & $12.2 \mathrm{~m} / \mathrm{s}( \pm 2 \%)$ \\
\hline $\mathrm{c}$ & $4.1 \mathrm{~kg}( \pm 0.1 \mathrm{~kg}), 2 \times 4$ 木片 & $15.3 \mathrm{~m} / \mathrm{s}( \pm 2 \%)$ \\
\hline $\mathrm{d}$ & $4.1 \mathrm{~kg}( \pm 0.1 \mathrm{~kg}), 2 \times 4$ 木片 & $24.4 \mathrm{~m} / \mathrm{s}( \pm 1 \%)$ \\
\hline $\mathrm{e}$ & $6.8 \mathrm{~kg}( \pm 0.1 \mathrm{~kg}), 2 \times 4$ 木片 & $22.4 \mathrm{~m} / \mathrm{s}( \pm 2 \%)$ \\
\hline
\end{tabular}

注 : 加撃体の種類を表す記号 $(\mathrm{a} \sim \mathrm{e})$ は, ISO 規格の原文では 大文字である。ASTM との混同を避けるため, 本報では小文 字で表記している。 
用され，ISO 規格では衝撃の大きな加撃体 e が採用さ れている点が異なる。また, ISO 規格では $2 \times 4$ 木片 に長さの指定はない。

\section{2）試験体と判定基準}

ASTM，ISO 規格ともに試験体は 3 体必要で，加撃 体をそれぞれの試験体の指定された位置に衝突させ, すべてが合格しなければならない。ASTM 規格では実 際の外装材を試験体として用いることを原則とし, 試 験体の大きさは規定されていない。一方, ISO 規格で は板ガラスを対象とし, 用いる試験体の大きさが $0.9 \mathrm{~m} \times 1.1 \mathrm{~m}$ と指定されている。加撃体の衝突に際して は, 鋼球と木片では各試験体への加撃位置と個数が異 なる。合格の判定基準は加撃体が貫通しないことであ る。さらに, ASTM では長さ $130 \mathrm{~mm}$, 幅 $1 \mathrm{~mm}$ 以上の 亀裂が生じないこと, および直径 $76 \mathrm{~mm}$ の球が通過す る穴が生じないこと, となっている。ISO 規格では長 さ $125 \mathrm{~mm}$ を超える亀裂が生じないこと, および直径 $76 \mathrm{~mm}$ の球が通過しないこと, となっている。なお, 加撃体による衝撃試験で亀裂, 開口等が生じなければ 合格とし, 亀裂, 開口等が生じても, 上記の判定に合 格した試験体は, 後述の圧力載荷試験に回され, 圧力 載荷試験後に上記の判定基準を満たし, かつ, 取付け 枠から脱落しなければ合格と判定される。

3）強風ゾーン

ASTM, ISO 規格いずれも強風ゾーンは 3 秒ガスト 風速で表される基本風速 $V_{\mathrm{b}}$ により 4 つの領域が定義 されているが，両者には微妙な違いがあり, ISO 規格 では同じ強風ゾーンに対して ASTM よりも風速の高 い地域が指定されている。

4）防御レベル

建物の防御レベルについては, ASTM 規格では建築 物の用途に応じた重要度によって3つのレベルが決め られている。ISO 規格では飛来物の劦威の程度に応じ た 4 つのレベルが決められている。

5）部材の設置高さ

ASTM, ISO 規格ともに試験対象となる部材の設置 高さによって加撃体を変え, 低層部では衝撃の大きな 加撃体を, 高層部では衝撃の小さな加撃体を用いる。 高層部の高さは ASTM 規格が地上 $9.1 \mathrm{~m}$ 以上, ISO 規 格が地上 $10 \mathrm{~m}$ 以上である。

6）圧力載荷試験

加撃体の衝突に耐えた試験体は，引き続き決められ た值と回数で繰り返し圧力載荷を受けた後に前述の 判定基準を満たし, 取付け枠からの脱落がなければ合
格となる。載荷される圧力の大きさは, ASTM 規格で はASCE 7 で与えられる設計風荷重により決まる風圧 力により, ISO 規格では強風ゾーンごとに指定される 風圧力により与えられる。

2.4 日本における試験および性能評価方法の策定に 向けて

日本において飛来物を発生させる強風としては, 台 風時の強風が主なものとして挙げられるので, 試験体 は衝撃後の継続的な風圧にも耐え, 被害の拡大を防ぐ ために大きな開口が開かないことを確認することが必 要となる。したがって, 加撃体を試験体に衝突させた 後に繰り返し圧力載荷試験を行い，基準以上の亀裂や 開口が生じないことを確認するのが妥当と考えられる。

日本における強風時の代表的な飛来物の一つとして, 木片に比べて硬く, また, $2 \mathrm{~g}$ の鋼球より重い瓦のよう な飛来物が挙げられる。したがって, それらの衝撃を 模擬する加撃体の提案を検討する必要がある。さらに, 国際的な耐衝撃試験および性能評価方法と整合性のと れたものとするためには，ASTM 規格を基に制定され た ISO 規格の方法に準ずることが好ましいと考えられ る。

以上の考察に基づき, ASTM や ISO 規格で用いられ る加撃体の再評価を行い, 日本における台風時による 強風時の耐衝撃試験用の加撃体を選定するための情報 が得られるように，以下の実験を計画した。

\section{3. 実験方法}

\section{1 試験体}

加撃体を衝突させる試験体としては普通フロートガ ラスの間にポリビニルブチラールの中間膜を挟んだ合 わせガラスを用いた。この合わせガラスは普通フロー トガラスに比べて耐衝撃性能が高く, 後述のように ISO 規格の幾つかの加撃体を用いた試験に合格する。 試験に用いた合わせガラスのガラス厚さは $3,5 \mathrm{~mm}$, 中 間膜の厚さは 30, 60, 90mil の組み合わせである。ここ で，mil は中間膜の厚さを表す単位で， $1 \mathrm{mil}=0.025 \mathrm{~mm}$ である。試験に際しては工場から直接送られた未使用 の試験体を用いることにより，製品の耐衝撃強度のば らつきを極力なくしている。すなわち, ここで用いら れる試験体は, 合わせガラスの而衝撃性状を明らかに するための試験体という意味だけではなく, 加撃体の 衝撃の強さを計る標準試験体としての役割を担う。

\section{2 加撃体}

耐衝撃試験に用いる加撃体は, ASTM および ISO 規 


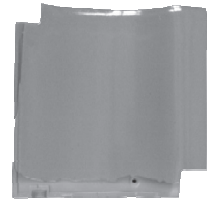

釉薬瓦艶あり

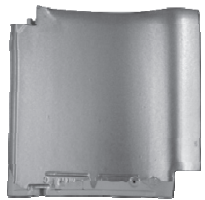

釉薬瓦艶なし

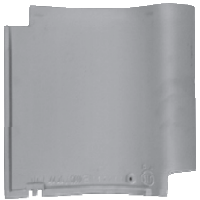

いぶし瓦
J 形 $56: 2.8 \mathrm{~kg}$ J 形 $53 \mathrm{~A}: 2.7 \mathrm{~kg}$ J 形 $53 \mathrm{~A}: 2.8 \mathrm{~kg}$

図 1 衝撃試験に用いた栈瓦 (JIS 規格, J 形)

Fig. 1 Roof tiles used for impact test (JIS,Jtype)

格で規定された鋼球と $2 \times 4$ 木片を用いる。さらに一 連の実験結果を考慮し, 瓦による衝撃との比較を行う ために $3 \mathrm{~kg}$ の $2 \times 4$ 木片も用いた。鋼球により模擬さ れる飛来物よりも大きく, 日本における強風時の代表 的な加撃体として, 和瓦を代表させることとし, 図 1 に示す JIS 規格による J 形 ${ }^{19)}$ の栈瓦 3 種類も加撃体と して用いた。

\section{3 実験装置}

実験は ISO 規格に従う外装材の耐衝撃試験が行え る装置 ${ }^{20)}$ 改良し，砲身の前に瓦を装填・射出するた めのガイドを設けたものを用いて行った。図 2 に示す ように瓦はエアータンクに接続された砲身の前方に 置かれ，砲身内に仕組まれたプッシュロッドにより押 し出される。瓦の周囲にはガイドが設けられ, 試験体 の指定された位置に向けて射出される。加撃速度は試 験体への加撃位置付近を高速度カメラにより撮影し て求めた。実験に先立つ試射により瓦の加撃速度は最 高で $31 \mathrm{~m} / \mathrm{s}$ まで出せることを確かめた。瓦以外の加撃

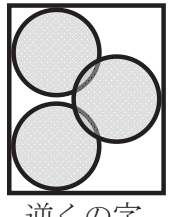

a. 加撃体として鋼球を用いる場合

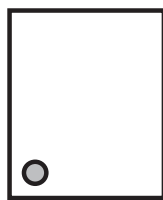

左下

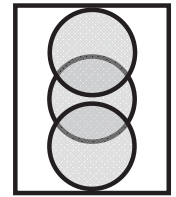

中央

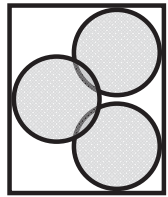

くの字

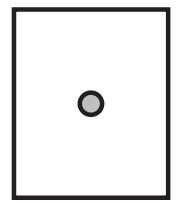

中央

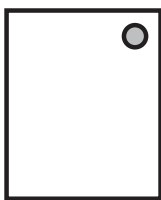

右上 b. 加撃体として $2 \times 4$ 木片および瓦を用いる場合

図 3 試験体一の加撃位置（丸で囲われた範囲）

Fig. 3 Impact locations (indicated by circles)

体を射出する装置，および，射出方法の詳細は文献 20 〜22)を参照されたい。

\section{4 試験手順}

実験は ISO 規格の手順に従った加撃試験と，それに 続く圧力載荷試験で行った。試験では，表 1,2 に示す 加撃体および瓦を, 図 3 に示寸 $1.1 \times 0.9 \mathrm{~m}^{2}$ の合わせガラ ス 3 枚に，それぞれ指定された位置に決められた速度 で衝突させた。なお，瓦の加撃位置は $2 \times 4$ 木片と同じ とした。加撃後， 3 枚すべての試験体で加撃体の衝突 による亀裂や割れなどの損傷がない場合は合格とし、 どれか 1 枚の試験体でも加撃体が貫通寸るか，ISO 規 格に従い $125 \mathrm{~mm}$ 以上の亀裂, $76 \mathrm{~mm}$ の固い球が通る開

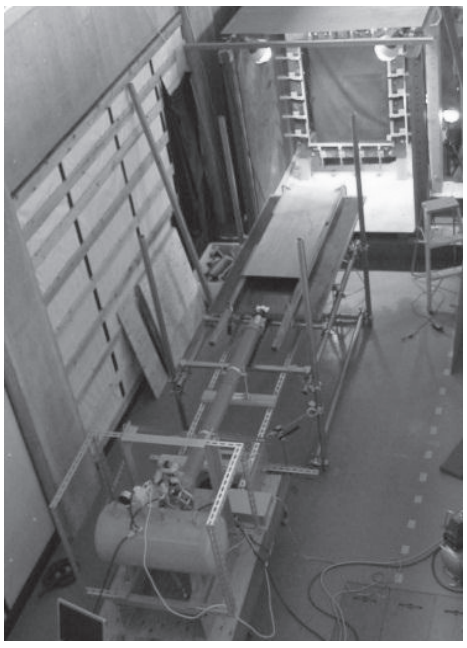

a. 概 観

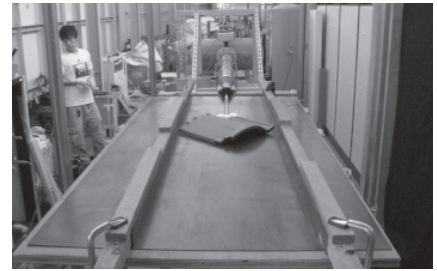

b. 瓦射出用のガイド （カバー無，前方から見る）

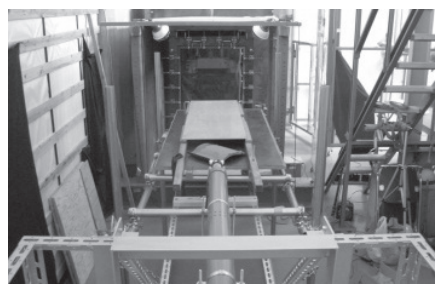

c. 瓦射出用のガイド

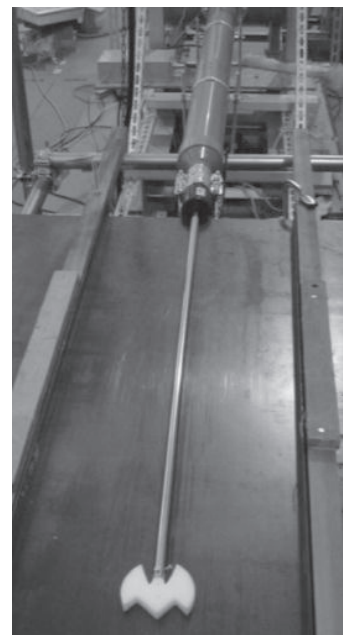

d. プッシュロッド

（カバー付，後方から見る）

図 2 衝撃破壞試験装置

Fig. 2 Overview of impact test device 
ロより大きな開口が生じた場合は不合格とした。次に, 損傷が上記の基準よりも小さい場合は, 繰り返し圧力 を載荷し, その後も亀裂や開口が上述の基準以上の大 きさにならず, 取付け枠からの脱落がなければ合格と した。ISO 規格で用いられる載荷圧力の大きさは強風 ゾーンに対応して決められる。強風ゾーンの区分分け に用いられる風速はASTM規格と同じく 3 秒ガス卜風 速であるが，日本での運用を考えると設計用の基準風 速である 10 分間平均風速に基づく值を用いることが 好ましい。そこで, 今回の実験では ISO 規格の強風ゾ ーンの風速值を 10 分間平均風速 $V_{10}$ に換算し, $32 \leqq V_{10}$ $<35 \mathrm{~m} / \mathrm{s}$ の範囲で表される強風ゾーン 1 に対応する最 大載荷圧力 $2490 \mathrm{~Pa}$ について風圧載荷実験を行った。

\section{4. 実験結果}

\section{1 鋼球による破壊性状}

鋼球 (ASTM の加撃体 A, ISO の加撃体 a) の場合, 図4 に示すように全ての試験体において加撃体は貫通 せず，中間膜にも亀裂はなく，開口も生じなかった。 図 5a に示すように加撃面側では加撃体の衝突箇所の ガラスは細かく破壊され, 周囲に短い放射状の亀裂が 生じ, さらにその外側を囲むように円周状の亀裂が生 じた。一方, 図 $5 \mathrm{~b}$ に示すように加撃面反対側のガラ スでは, 鋼球の衝突箇所のガラスは細かく破壊され, その中心から放射状に亀裂が生じたが，加撃面側に見 られたような外側を囲む円周状の亀裂は少なかった。 また, 加撃面反対側のガラスの亀裂はガラス中央部に 加撃した場合に多くみられ, 取付け枠に近い部分に加 撃した場合には加撃面反対側のガラスが割れない場 合が多かった。加撃後の圧力載荷試験ではガラスに亀 裂の伸展が見られる場合があったが，中間膜に変化は
なかったので, ISO 規格判定に合格した。結果を表 3 にまとめる。

鋼球のように硬い加撃体を衝突させた場合, 加撃面 側のガラスには局所的な狭い範囲に短時間に大きな衝 撃が加わり割れる。一方, 加撃面反対側のガラスには, 中間膜により襄側へ伝達される応力が緩和されるため, 加撃面側よりも応力がゆっくりと加わり, 衝撃的な破 壊を起こさない。そのため, 加撃面反対側のガラスは 荷重を漸増させていった場合と同様な割れ方をすると 考えられ，そのときはガラス厚さが厚いほど，あるい は周囲の取付け枠までの距離が短く拘束が強くなるほ ど, 衝突部分のガラスの剛性が大きくなって割れにく くなると考えられる。

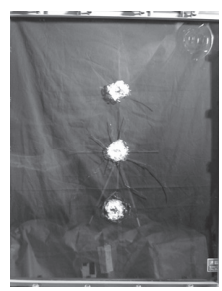

5mm-30mil: 中央

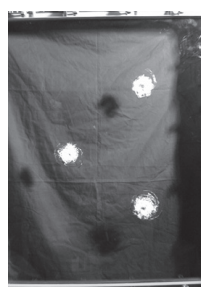

5mm-60mil: くの字
図 4 鋼球（ISO 加撃体 a) による加撃結果

Fig. 4 Test results using steel balls (ISO missile type a)

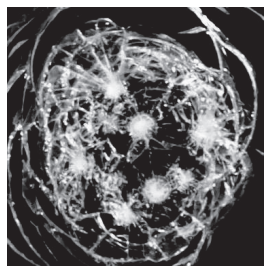

a. 加撃面側

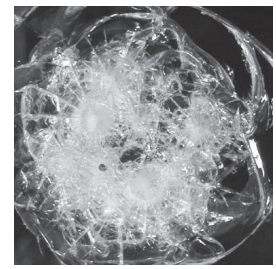

b.加撃面反対側
図 5 鋼球（ISO 加撃体 a) による加撃部分の詳細

Fig. 5 Details of impact locations by steel balls (ISO missile type a)

表 $32 \mathrm{~g}$ 鋼球（ISO の加撃体 a) による衝撃試験結果

Table 3 Test results using $2 \mathrm{~g}$ steel balls (ISO missile type a)

\begin{tabular}{|c|c|c|c|c|c|c|c|c|c|c|}
\hline \multirow{2}{*}{ ガラス厚 } & \multirow{2}{*}{ 中間膜厚 } & \multicolumn{3}{|c|}{ 加撃パターン> } & \multicolumn{3}{|c|}{ 加撃パターン } & \multicolumn{3}{|c|}{ 加撃パターン< } \\
\hline & & 左上 & 右中央 & 左下 & 右上 & 左中央 & 右下 & 上 & 中央 & 下 \\
\hline \multirow{2}{*}{$3 \mathrm{~mm}$} & $30 \mathrm{mil}$ & $\Delta$ & $\Delta$ & $\Delta$ & $\Delta$ & $\Delta$ & $\Delta$ & $\boldsymbol{\Delta}$ & $\boldsymbol{\Delta}$ & $\Delta$ \\
\hline & $60 \mathrm{mil}$ & - & - & - & {$[\Delta]$} & {$[\mathbf{\Delta}]$} & {$[\mathbf{\Delta}]$} & - & - & - \\
\hline \multirow{3}{*}{$5 \mathrm{~mm}$} & 30mil & - & - & - & {$[\Delta]$} & {$[\mathbf{\Delta}]$} & {$[\Delta]$} & - & - & - \\
\hline & $60 \mathrm{mil}$ & $\Delta$ & $\Delta$ & $\Delta$ & $\Delta$ & $\Delta$ & $\Delta$ & $\Delta$ & $\Delta$ & $\Delta$ \\
\hline & 90mil & - & - & - & {$[\Delta]$} & {$[\mathbf{\Delta}]$} & {$[\Delta]$} & - & - & - \\
\hline
\end{tabular}

注 : 表中の記号の意味は以下の通りである。

$\boldsymbol{\Delta}$ : 合わせガラスの加撃面, および, 反対側の面ともに亀裂が見られた。

$\Delta$ : 合わせガラスの衝撃面のみに亀裂が見られた。[]：圧力載荷試験を行っていない。

- : 試験を行っていない。 mil はフィルム厚さの単位 : $1 \mathrm{mil}=0.025 \mathrm{~mm}$ 
表 4 合わせガラスの耐衝撃試験および性能判定結果

Table 4 Judgment results of laminated glasses for impact resistance performance based on the ISO standard

\begin{tabular}{|c|c|c|c|c|c|c|c|c|c|c|c|c|c|c|c|c|}
\hline \multirow{4}{*}{$\begin{array}{c}\text { 試験体の } \\
\text { 種類 } \\
\text { ガラス厚 } \\
+ \\
\text { 中間膜厚 }\end{array}$} & \multicolumn{16}{|c|}{ 加撃体の種類 } \\
\hline & $\begin{array}{c}\text { ISO - a } \\
\text { ASTM - A }\end{array}$ & \multicolumn{3}{|c|}{ ASTM - B } & \multicolumn{2}{|c|}{$\begin{array}{c}\text { ISO - b } \\
\text { ASTM - C }\end{array}$} & \multicolumn{3}{|c|}{$\begin{array}{l}2 \times 4 \text { 木片 } 3 \mathrm{~kg} \\
\text { 速度 } 15.2 \mathrm{~m} / \mathrm{s}\end{array}$} & \multicolumn{3}{|c|}{$\begin{array}{c}\text { ISO - c } \\
\text { ASTM - D }\end{array}$} & \multicolumn{3}{|c|}{$\begin{array}{c}\text { ISO - d } \\
\text { ASTM - E }\end{array}$} & \multirow{2}{*}{$\begin{array}{l}\text { ISO } \\
\text { 性能 } \\
\text { 判定 }\end{array}$} \\
\hline & \multicolumn{15}{|c|}{ 加撃位置 } & \\
\hline & $>$ 中央 $<$ & 右上 & 中央 & 左下 & 右上 中央 & 左下 & 右上 & 中央 & 左下 & 右上 & 中央 & 左下 & 右上 & 中央 & 左下 & 結果 \\
\hline $3 \mathrm{~mm}+30 \mathrm{mil}$ & $\Delta \Delta \Delta$ & $\Delta$ & $\Delta$ & $\Delta$ & {$[\Delta][\Delta]$} & $x$ & - & - & - & - & - & - & - & - & - & $\mathrm{a}$ \\
\hline $3 \mathrm{~mm}+60 \mathrm{mil}$ & $-[\Delta]-$ & - & - & - & $\Delta$ & $\Delta$ & - & - & - & - & - & $x$ & - & - & - & b \\
\hline $5 \mathrm{~mm}+30 \mathrm{mil}$ & $-[\Delta]-$ & - & - & - & $\Delta$ & $\Delta$ & - & - & $\times$ & - & $x$ & - & - & - & - & b \\
\hline $5 \mathrm{~mm}+60 \mathrm{mil}$ & $\Delta \Delta \Delta$ & - & - & - & $\Delta$ & $\Delta$ & $\Delta$ & $\Delta$ & $\Delta$ & $x$ & $\Delta$ & $x$ & - & - & - & $\mathrm{b}$ \\
\hline
\end{tabular}

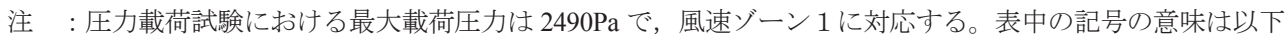
の通りである。

$\Delta \quad$ : 開口は生じなかったが，亀裂が生じた。[]が付かないものは圧力載荷試験にも合格した。

$\times \quad$ : 加撃体が貫通したか, $76 \mathrm{~mm}$ 以上の開口か， $125 \mathrm{~mm}$ 以上の亀裂が生じた ; ISO 規格に不合格であった。

- : 試験を行っていない。[] : 圧力載荷試験を行っていない。

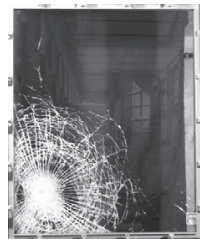

左下

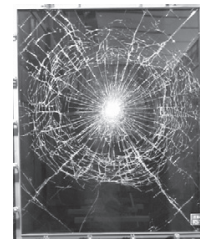

中央

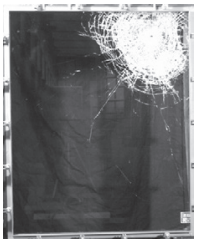

右上

図 6 ISO の加撃体 $\mathrm{b}$ による合わせガラス $5 \mathrm{~mm}+30 \mathrm{mil}$ へ の加撃結果

Fig. 6 Impact test results of laminated glass $5 \mathrm{~mm}+30$ mil using missile b of ISO

\section{2 木片による破壊性状}

ASTM 加撃体 B ではガラス厚 $3 \mathrm{~mm}$, 中間膜厚 $30 \mathrm{mil}$ （以下，合わせガラスの種類はガラス厚+中間膜厚 : $3 \mathrm{~mm}+30 \mathrm{mil}$ のように表記）の場合に，ISO の加撃体 b では $3 \mathrm{~mm}+60 \mathrm{mil}$ およびガラス厚 $5 \mathrm{~mm}$ のすべての中間 膜厚さに対してガラスは割れたが ISO 規格で規定さ れた以上の開口あるいは亀裂が生じず (図 6), 圧力載 荷試験においても ISO 規格の判定に合格した。ISO の 加撃体 c では $5 \mathrm{~mm}+90 \mathrm{mil}$ のみで規定以上の開口ある いは亀裂が生じず, 圧力載荷試験においても ISO 規格 の判定に合格した。ISO の加撃体 $\mathrm{b}, \mathrm{c}$ において，ガラ スの厚さ, 中間層の厚さによる破壊性状には大きな違 いが見られなかった。ISO の加撃体 $\mathrm{d}$ は $5 \mathrm{~mm}+90 \mathrm{mil}$ も貫通した。以上の結果を表 4 にまとめる。

ガラスの破壊性状を詳しく見ると, 加撃体が衝突し た部分では細かい亀裂が入り, 周囲に伸展するにした がって亀裂の間隔は大きくなった。亀裂には加撃点を 中心と寸る円周状のものと, 放射状のものが観察され た。円周状のものは, 図 7 に示寸ように加撃面側に, 放射状のものは加撃面反対側のガラスに多く生じた。
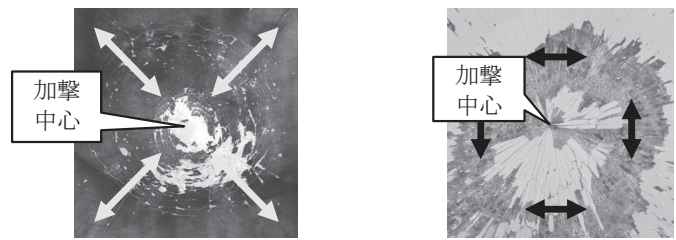

a. 加撃面側（円周状） b. 加撃面反対側（放射状）

図7加撃点周囲の亀裂の状況と対応寸る応力の方向

Fig. 7 Clacks around impact point and directions of corresponding stresses

このことから、加撃側のガラス面は加撃点で割れた後, 加撃点を中心に押し込むように曲がり，放射状の引張 力（図 7a）を大きく受けて破壞すると考えられる。一 方, 加撃面反対側のガラス面では, 加撃点を中心とし た円周方向の引張力（図 7b）を大きく受けて破壞する と考えられる。また, $5 \mathrm{~mm}+60 \mathrm{mil}$ の試験体に対する ISO の加撃体 b,c の加撃では, 中央部を加撃した場合の方 が取付け枠に近い部分を加撃した場合よりも割れにく くなった。このように $2 \times 4$ 木片による衝撃に対しては ガラス面が大きくたわむことのできる中央部に加撃さ れたときの方が耐衝撃性能は高いことがわかった。木 片を用いた加撃では衝突した瞬間に木片の接触面付近 が変形し, 鋼球が衝突した場合ほど局所的に大きな衝 撃がガラスには生じないため, 衝突位置周辺に衝撃に よる応力が伝播した後, 破壊が生じると考えられる。 このとき，端部よりも中央に加撃した場合の方が周囲 の取付け枠までの距離が長く, 剛性が相対的に小さく なって大きく変形できるので，破壊までに消費される エネルギーが大きくなり， ガラスが破壊する応力に達 する前に加撃体が止められ, 結果として端部に加撃し 


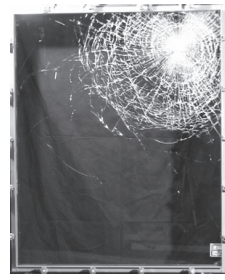

$(\mathrm{m} / \mathrm{s})$

$15.5 \times$

$15.2 \triangle$

$15.1 \triangle$

$15.1 \triangle$

$14.9 \triangle$

$14.3 \triangle$

$14.2 \triangle$

$13.9 \triangle$

図中 $\times$ は ISO 規格

の判定に不合格,

、は亀裂または開

口が生じたが ISO

規格の規定には

合格であること

を表す。

図 8 合わせガラス $5 \mathrm{~mm}+60 \mathrm{mil}$ の試験結果

数字は $2 \times 4$ 木片 $3 \mathrm{~kg}$ 在上に加撃した場合の不貫通速を示す。

Fig. 8 Impact test results for laminated glass $5 \mathrm{~mm}+60 \mathrm{mi}$ using $3 \mathrm{~kg} 2 \times 4$ timber missile impacted at upper right corner

た場合よりも割れにくくなると考えられる。

ここでは後述の瓦の衝撃を評価するために，ISOの 加撃体 $\mathrm{b}$ と $\mathrm{c}$ の間の質量をもつ加撃体として $2 \times 4$ 木 片 $3 \mathrm{~kg}$ を設定し, その衝撃を評価した。その際, 上記 のように木片による衝撃に対しては, 取付け枠に近い 左下あるいは右上端部分に加撃する方が耐衝撃性能 は低くなり，ガラスにとっては危険側となる。したが って, 端部への加撃により ISO 規格で規定された以上 の亀裂または開口が生じない最大の速度を“不貫通速 度”とし，この不貫通速度で而衝撃性能を評価した。 図 8 に示寸実験結果のとおり, $5 \mathrm{~mm}+60 \mathrm{mil}$ の合わせガ ラス試験体に対して不貫通速度は $15.2 \mathrm{~m} / \mathrm{s}$ であった。

\section{3 瓦による破壊性状}

本研究では瓦に対する合わせガラスの耐衝撃破壊 性状も明らかにするため, 瓦を加撃体として ISO 規格 に準じた試験を行った。合わせガラスの耐衝撃性能の 評価に先立ち, 瓦の衝撃による合わせガラスの破壊性 状の変化を衝突の姿勢による違い, 瓦の種類による違 い, 衝突位置による違いについて調べた。その際, ISO 規格の判定に従う亀裂や開口が生じ不合格となる最 低の速度を“貫通速度”と呼ぶことにし，瓦による衝撃 の強さはこの貫通速度で評価することにする。屋根瓦 には種々の種類があるが, ここでは住宅の屋根に一般 的に用いられる JIS 規格の J 形栈瓦を加撃体として選 んだ。強風によって瓦が飛散する際, 割れた破片が飛 散する場合も考えられるが，割れずに衝突する場合が 最も衝撃が大きいと考えられるので，ここでは，一枚 を健全な形で衝突させた場合の貫通速度で評価する ことにする。

1）加撃姿勢による違い

瓦の形状は図 1 に示すように対称ではなく, 試験体 にどのような姿勢で衝突するかによっても合わせガ ラスの破壞性状が異なると考えられる。そこで, 加撃 の姿勢を変えて貫通速度を調べた。加撃姿勢は図 9 に

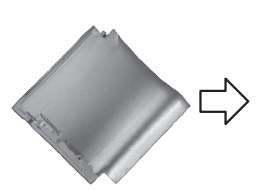

No.1 : $21.1 \mathrm{~m} / \mathrm{s}$

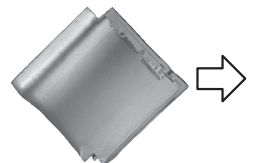

No.3 : $24.0 \mathrm{~m} / \mathrm{s}$

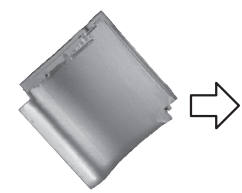

No. $2: 20.9 \mathrm{~m} / \mathrm{s}$

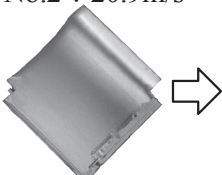

No. $4: 23.3 \mathrm{~m} / \mathrm{s}$
図 9 加撃姿勢による貫通速度の違い

Fig. 9 Variation of penetrating speed with impact positions

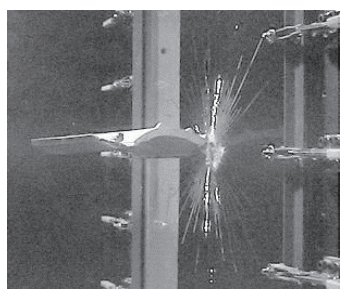

衝突 0.0005 秒後

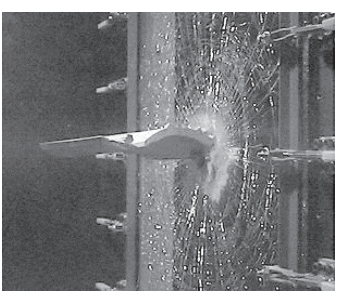

衝突 0.0015 秒後
図 10 高速度カメラでとらえた瓦の衝突の様子

Fig. 10 Photos of impact recorded by high-speed video camera

示す No.1〜4 の 4 通りに変化させ, 釉薬瓦艶なしを $5 \mathrm{~mm}+30 \mathrm{mil}$ の合わせガラスの中央に加撃した。

実験結果によると, 貫通速度が最も低くなる加撃位 置は, 図中欠き込みの有る加撃姿勢 No.2 であった。図 10 に示寸ように, 衝突時のビデオ画像をみると，瓦が ガラスに衝突する際，ガラスに接触した部分から瓦は 衝撃によって粉砕される。粉砕される範囲は衝突速度 や瓦の種類により微妙に変化するが，粉砕片は瓦とガ ラスの間に挟まり緩衝材となって，ガラスへの瓦の衝 撃を和らげる傾向を示寸。加撃姿勢 No.2 のように欠き 込みがあり，2つの角がある部分で衝突すると，瓦が 貫通する際に先行する角がガラスに当たった時点でガ ラスが割れる。その際, 後に続く 2 つ目の角は粉砕さ れることなく割れたガラスに突入することになり，中 間膜を直接引き裂く。その他の加撃姿勢で衝突する際 には，中間膜と瓦の間には前述のように粉砕片が挟ま り，中間膜を引き裂く力を弱める。加撃姿勢 No.4 にも 2 つの角があるが，この場合はほぼ正方形の欠き込み があり，2 つの角がほぼ同時に当たるので，加撃姿勢 No.2のように角が中間膜を直接引き裂くことは少なく, 中間膜を引き裂く力は弱まる。さらに、加撃姿勢 No.2 は基本的には釉薬で覆われた 2 つる角のうち先行す る 1 つの角から衝突する加撃方法であり、釉薬で覆わ 


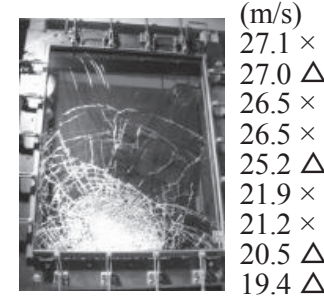

左下

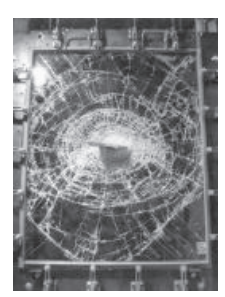

$(\mathrm{m} / \mathrm{s})$

$31.0 \times$

$30.4 \triangle$

$29.4 \Delta$

$29.4 \times$

$28.0 \triangle$

$28.0 \triangle$

$27.1 \triangle$

$26.7 \triangle$

中央

$21.6 \triangle$
図 11 瓦の加撃位置による貫通速度の違い（合わせ ガラス $5 \mathrm{~mm}+60 \mathrm{mil}$ )

Fig. 11 Variation of penetrating speed with impact point (laminated glass $5 \mathrm{~mm}+60 \mathrm{mil}$ )

図中×は ISO 規格の判定に不合格, $\Delta$ は亀裂または開口が生 じたが ISO 規格の規定に合格したことを表す。

れた 1 つの角から衝突する加撃姿勢 No.1 による状況 を包含するものである。以上の理由により，加撃姿勢 No.2 のような段違いの欠き込みがある位置で衝突し た場合に，瓦は最も低い速度で貫通することになり， ガラスにとって最も危険となる。

以上の結果から, 試験では加撃姿勢 No.2 で瓦を衝 突させる, 寸なわち, ガラスにとっては最も危険な加 撃姿勢で衝突させることとした。なお，瓦を角以外の 辺で衝突させた場合や面で衝突させた場合には，上記， 角部による衝突の場合よりも衝撃は小さくなり, 角で 衝突させた場合よりも貫通速度は大きくなることを 確認してある。

2）瓦の種類による違い

瓦の種類による貫通速度の変化を $5 \mathrm{~mm}+30 \mathrm{mil}$ の合 わせガラスを試験体として調べた。瓦は試験体の中央 に衝突させ, 図 1 に示した釉薬瓦 2 種類 (艶あり $2.8 \mathrm{~kg}$, 艶なし $2.7 \mathrm{~kg}$ ) と, いぶし瓦 1 種類（2.8kg）を用いた が，貫通速度はそれぞれ 21.7, 20.9, 20.9m/s となり，瓦 の違いによる貫通速度の差は小さかった。

3）衝突位置による違い

瓦が試験体に衝突する位置による貫通速度の違い を $5 \mathrm{~mm}+60 \mathrm{mil}$ の合わせガラスを試験体として調べた。 図 11 に数字で示すように瓦を衝突させる速度を少し
ずつ変化させて, ISO 規格の判定に不合格となる貫通 速度（図中×で表示）を求めた。その結果，衝突位置 が中央の場合の貫通速度は $29.4 \mathrm{~m} / \mathrm{s}$, 左下の場合 $21.2 \mathrm{~m} / \mathrm{s}$ となり, 左下の方が中央よりも貫通速度が低くなり, ガラスの瓦に対する耐衝撃性能は弱くなった。さらに, ガラス厚および中間膜厚を変化させた試験により，ガ ラス厚および中間膜厚が厚くなるほど貫通速度は大き くなることがわかった。

\section{5. 耐衝撃試験用の標準加撃体の提案}

前章の実験結果をふまえて, 日本国内用の規準やガ イドラインの作成に資するため, 耐衝撃試験に用いる 標準加撃体を考察する。試験評価方法は ISO 規格と同 様なものを想定する。

\section{1 合わせガラスを用いた比較}

合わせガラスに対して、瓦と同じ ISO 規格による判 定結果を得る木片の衝突速度を求めるために，合わせ ガラス $5 \mathrm{~mm}+60 \mathrm{mil}$ を試験体として試験を行い，瓦お よび $2 \times 4$ 木片の結果を比較した。ISO 規格による亀裂 および開口の判定基準を満たす速度を求めると，瓦で は $20.5 \mathrm{~m} / \mathrm{s}$, ISO の加撃体 b と同様な質量 $2.05 \mathrm{~kg}$ の $2 \times$ 4 木片では $21.7 \mathrm{~m} / \mathrm{s}, 3 \mathrm{~kg}$ の質量をもつ $2 \times 4$ 木片では $15.2 \mathrm{~m} / \mathrm{s}$, ISO の加撃体 $\mathrm{c}, \mathrm{d}$ と同様な質量 $4.1 \mathrm{~kg}$ の $2 \times 4$ 木片では $14.4 \mathrm{~m} / \mathrm{s}$ となった。

\section{2 提案する標準加撃体}

前節の結果は, 速度 $20.5 \mathrm{~m} / \mathrm{s}$ の瓦がもつ衝撃が ASTM 加撃体 C および ISO 加撃体 b $(2 \times 4$ 木片 $2.05 \mathrm{~kg}$, 速度 $12.2 \mathrm{~m} / \mathrm{s}$ ）のもつ衝撃よりも大きく，ASTM 規格の加撃 体 D および ISO 規格の加撃体 c $(2 \times 4$ 木片 $4.1 \mathrm{~kg}$, 速度 $15.3 \mathrm{~m} / \mathrm{s})$ のもつ衝撃よりも小さいことを示している。

日本における耐衝撃試験用の標準加撃体を提案する にあたり, ASTM および ISO 規格と整合性のとれたも のとし，瓦の衝撃を評価できるような加撃体を追加す ることとした。すなわち, 提案する標準加撃体は表 5 のように I から VII までの 7 種類とした。この表には

表 5 新しく提案する耐衝撃試験用の標準加撃体の種類

Table 5 Types of newly proposed standard missiles for impact resistant test

\begin{tabular}{|c|c|c|c|c|c|}
\hline 種類 & 質量（誤差), & 材質 & 衝突速度 & (䛊差) & 参 考 \\
\hline I & $2 \mathrm{~g}( \pm 0.1 \mathrm{~g} /$ 個 $)$, & 鋼球 10 個 & $39.7 \mathrm{~m} / \mathrm{s}$ & $( \pm 1 \%)$ & ISO 加撃体 $\mathrm{a}$, ATSM 加撃体 A に相当 \\
\hline II & $0.9 \mathrm{~kg}( \pm 0.1 \mathrm{~kg})$ & $2 \times 4$ 木片 & $15.3 \mathrm{~m} / \mathrm{s}$ & $( \pm 2 \%)$ & ATSM 加撃体 B に相当 \\
\hline III & $2.1 \mathrm{~kg}( \pm 0.1 \mathrm{~kg})$ & $2 \times 4$ 木片 & $12.2 \mathrm{~m} / \mathrm{s}$ & $( \pm 2 \%)$ & ISO 加撃体 b, ATSM 加撃体 $\mathrm{C}$ に相当 \\
\hline IV & $3.0 \mathrm{~kg}( \pm 0.1 \mathrm{~kg})$ & $2 \times 4$ 木片 & $15.3 \mathrm{~m} / \mathrm{s}$ & $( \pm 2 \%)$ & 衝突速度 $20.5 \mathrm{~m} / \mathrm{s}$ の瓦に相当 \\
\hline $\mathrm{V}$ & $4.1 \mathrm{~kg}( \pm 0.1 \mathrm{~kg})$ & $2 \times 4$ 木片 & $15.3 \mathrm{~m} / \mathrm{s}$ & $( \pm 2 \%)$ & ISO 加撃体 $\mathrm{c}$, ATSM 加撃体 D に相当 \\
\hline VI & $4.1 \mathrm{~kg}( \pm 0.1 \mathrm{~kg})$ & $2 \times 4$ 木片 & $24.4 \mathrm{~m} / \mathrm{s}$ & $( \pm 1 \%)$ & ISO 加撃体 $\mathrm{d}$, ATSM 加撃体 $\mathrm{E}$ に相当 \\
\hline VII & $6.8 \mathrm{~kg}( \pm 0.1 \mathrm{~kg})$ & ，2×4木片 & $22.4 \mathrm{~m} / \mathrm{s}$ & $( \pm 2 \%)$ & ISO 加撃体 e に相当 \\
\hline
\end{tabular}


ASTM および ISO 規格で用いられる加撃体に相当す る衝撃をもった加撃体を含み, ISO の加撃体 $\mathrm{b}$ と $\mathrm{c}$ に 相当する加撃体 III と V の間に, 速度 $20.5 \mathrm{~m} / \mathrm{s}$ の瓦と 同等の衝撃をもつ $3 \mathrm{~kg}$ の $2 \times 4$ 木片の加撃体 IV を追加 してある。耐衝撃試験における運用に際しては, 評価 対象となる部材が用いられる建物の防御レベル, 強風 ゾーン, 部材の設置高さなどにより表 5 の I から VII までの中から, 適当な加撃体を選ぶことになる。

なお, 強風時の瓦の代表的な衝突速度に関しては, 台風に伴う平均風速 $25 \mathrm{~m} / \mathrm{s}$ の暴風域内で突風率を 2 と して, 最大瞬間風速が $50 \mathrm{~m} / \mathrm{s}$ 程度吹いている状況を考 えている。塊状の物体の飛散を解析した English ら ${ }^{23)}$ の結果によると, $3 \mathrm{~kg}$ の石の塊は風速 $50 \mathrm{~m} / \mathrm{s}$ で $25 \mathrm{~m}$ 飛 散すると風速の約 $40 \%, 20 \mathrm{~m} / \mathrm{s}$ に達する。塊状の物体 と平板状の物体では飛散性状は異なるが, 野田ら ${ }^{24}$ によると, 風向風速が変化する流れの中では, 平板の 平均的な飛散軌道は立川数に依存するので, 地面付近 の乱れた流れの中では塊状の物体と平板状の物体で は, 立川数が同程度であれば平均的な飛散軌道には大 差がないと考えられ，上述の石の塊と同程度の立川数 をもつ瓦の代表的な衝突速度は, 低層住宅の屋根から 瓦が飛んだ場合, 台風時に暴風域内で $20 \mathrm{~m} / \mathrm{s}$ 程度であ ると推定した。

また、 $5 \mathrm{~mm}+60 \mathrm{mil}$ の合わせガラスに瓦を左下に加撃 した場合、ISO 規格の判定が不合格となる確率をべー タ分布で近似し、4.3節 3) で得られた 9 回の実験值を 用いてパラメータを最適化すると、衝突速度 $21.2 \mathrm{~m} / \mathrm{s}$ 以下で ISO 規格の判定に合格する確率は $60 \%$ 程度と 見積もられた。

\section{6. まとめ}

本研究では, 台風の強風による飛散物に対する外装 材の而衝撃試験および性能評価方法について既存の 方法を概観し, 日本での適用について検討した。また, 日本における外装材の耐衝撃試験および性能評価方 法の提案に向けた基礎資料を得ることを目的として, ISO 16932 の手順に従った合わせガラスの耐衝撃試験 を行い, 鋼球, 木片, 瓦を加撃体として用い破壊性状 を明らかにした。さらに, 得られた結果をもとに, 耐 衝撃試験用の標準加撃体の提案を行った。

今回の試験の範囲内において, 明らかになった合わ せガラスの耐衝撃破壊性状を以下にまとめる。

・鋼球（ASTM 加撃体 A および ISO 加撃体 a) による 加撃の場合, 中央に加撃した場合よりも, 周囲の取
付け枠に近い端部に加撃した場合の方が割れにくく なった。

・鋼球による加撃の場合, 全ての試験体（ガラス厚さ $3 \mathrm{~mm}$ と中間膜 $30,60 \mathrm{mil}$ の組み合わせ, および, ガラ 不厚さ $5 \mathrm{~mm}$ と中間膜 $30,60,90 \mathrm{mil}$ の組み合わせ）に おいて加撃体は貫通せず, 中間膜にも亀裂はなく, 開口も生じなかった。加撃後の圧力載荷試験ではガ ラスに亀裂の伸展が見られる場合があったが，中間 膜に変化はなかったので, ISO 規格の耐衝撃性能の 評価判定に合格した。

・ $2 \times 4$ 木片による加撃の場合, 周囲の取付け枠に近い 端部に加撃した場合よりも, 中央に加撃した場合の 方が割れにくくなった。

・ $2 \times 4$ 木片について, ASTM 加撃体 B から E まで, ISO 加撃体 b から d まで, および, $3 \mathrm{~kg}$ の加撃体につ いて, ISO 規格に従い耐衝撃性能評価に合格するガ ラス厚と中間膜の厚さの組み合わせを明らかにした。 ・ $2 \times 4$ 木片を加撃した場合は, 加撃面側と加撃面反対 側ではガラスの破壊性状が異なり, 加撃面側では加 撃点を中心とする円周状の亀裂が，加撃面反対側で は放射状の亀裂が多く観察された。

・瓦の加撃に関しては, 衝突の姿勢による違い, 瓦の 種類による違い, 衝突位置による違いに対寸る耐衝 撃破壊性状を明らかにした。衝突の姿勢については, 段違いの欠き込みがある位置で衝突した場合に最も 低い速度で貫通し, ガラスにとって最も危険となる ことがわかった。瓦の種類については，ほぼ同じ質 量の釉薬瓦 2 種類と, いぶし瓦 1 種類を用いて合わ せガラスの破壊性状を調べたが，違いはほとんど見 られなかった。衝突位置に関しては, 周囲の取付け 枠に近い端部に加撃した場合よりも, 中央に加撃し た場合の方が割れにくくなった。

・瓦の衝撃に関しては，合わせガラスに同じ破壞性状 を生じさせる $2 \times 4$ 木片の加撃速度を明らかにした。 それによると, 速度 $20.5 \mathrm{~m} / \mathrm{s}$ の瓦は, $2.05 \mathrm{~kg}$ の $2 \times 4$ 木片で $21.7 \mathrm{~m} / \mathrm{s}, 3 \mathrm{~kg}$ の $2 \times 4$ 木片で $15.2 \mathrm{~m} / \mathrm{s}, 4.1 \mathrm{~kg}$ の $2 \times 4$ 木片で $14.4 \mathrm{~m} / \mathrm{s}$ と同じであることがわかった。 最後に, 上記の結果を基に日本での運用に適するよ うに瓦の衝撃を評価できるような加撃体を加え,

ASTM およびISO 規格と整合性のとれたものとして耐 衝撃試験用の標準加撃体を提案した。

なお，本論文は文献 22, 25〜27)で発表した内容を一 部修正，加筆したものである。 
謝辞

本研究は, 平成 20-22 年度科学研究費補助金基盤研 究(B)一般「強風下における飛来物による外装材の破壊 性状に関する研究」および, 平成 23-25 年度科学研究 費補助金基盤研究(B)一般「強風下における飛来物によ る外装材の破壊性状に関寸る研究」の補助をうけて行 われた。また，合わせガラス試験体は板硝子協会から 提供していただいた。ここに記して謝意を表します。

\section{参考文献}

1) 加茂 正人, 丸山敬, 河井 宏允, 前田 豊, 西村 宏 昭, 「ガラスの飛散物耐衝撃試験 その 1 フロート ガラス他」, 日本建築学会大会学術講演梗概集 B-1, pp. 123-124, (2010)

2) 前田 豊, 加茂 正人, 丸山 敬, 河井 宏允, 西村 宏 昭, 「ガラスの飛散物耐衝撃試験 その 3 フィルム 貼りガラス」, 日本建築学会大会学術講演梗概集 B1,pp. 127-128, (2010)

3) International Organization for Standardization (ISO) ISO 16932, "Glass in Building - Destructive windstorm resistant security glazing - Test and classification", (2008)

4)「建築基準法第 20 条（平成 23 年改正)」,(2011)

5)「建築基準法施行令第 39 条,第 82 条の 4 ,第 87 条 (平 成 24 年改正)」,(2012)

6)「建設省告示第 1458 号」, (2000), 「建設省告示第 1454 号」, (2000), 「国土交通省告示第 1231 号(平成 19 年改正)」, (2007)

7) 日本建築学会, 「建築物荷重指針・同解説」, (2004)

8) Darwin Reconstruction Commission, "Darwin area building manual", Darwin, NT, Australia, (1976)

9) SBCCI, Section 1205.4, "Windborne debris, proposed change to the Standard Building Code", Item No. 166-83, SBCCI Blue Book (Southern Building Code Congress International, Inc. Birmingham, 1983), pp. B-255-B-260

10) J. E. Minor, "Windborne debris and the building envelope", Journal of Wind Engineering and Industrial Aerodynamics, Vol. 53, pp. 207-227, (1994)

11) FBC-TAS 201, "Florida Building Code 2004", Building, (2004)

12) Federal Emergency Management Agency, FEMA P-361, "Design and Construction Guidance for Community Safe Rooms, Second Edition”, (2008)

13) U.S. Department of Energy, DOE STD-1020, "Natural
Phenomena Hazards Design and Evaluation Criteria for Department of Energy Facilities", (2002)

14) American Society of Civil Engineers, ASCE 7-05, "Minimum Design Loads for Buildings and Other Structures", (2005)

15) 日本工業規格, JIS R 3205 : 2005,「合わせガラス」

16) 丸山敬,「飛散物に対する外装材の耐衝撃性能の評 価方法について」, 日本風工学会誌, Vol. 35, No. 1, pp. 33-40, (2010)

17) ASTM E1996-04, "Standard Specification for Performance of Exterior Windows, Curtain Walls, Doors, and Impact Protective System Impacted by Windborne Debris in Hurricanes", ASTM (American Society for Testing and Materials) Standard, (2004)

18) American Society for Testing and Materials, ASTM E1886-04, "Standard Test Method for Performance of Exterior Windows, Curtain Walls, Doors, and Impact Protective Systems Impacted by Missile(s) and Exposed to Cyclic Pressure Differentials", (2004)

19）日本工業規格，JIS A 5208，「粘土がわら」

20) 丸山敬, 河井 宏允, 西村 宏昭, 加茂 正人, 「外装 材耐衝撃性能試験用エアーキャノン」, 日本風工学 会論文集, Vol. 34, No. 2, pp. 31-38, (2009)

21) 丸山敬, 河井 宏允, 西村 宏昭, 加茂 正人, 「試作 された耐衝撃性能試験用エアーキャノンの性能」, 京都大学防災研究所年報, 第 52 号 B, pp. 481-489, (2009)

22) 丸山敬, 加茂 正人, 河井宏允, 前田 豊, 西村 宏昭，「ガラスの飛散物衝撃試験 その 2 合わせガ ラス」, 建築学会年次大会梗概集, B-1, 構造 I, pp. 125-126, (2010)

23) E. C. English, J. D. Holmes, "Non-dimensional solutions for trajectories of wind-driven compact objects", Proceedings of The Fourth European and African Conference on Wind Engineering, (2005)

24) 野田 稔, 長尾 文明, 政井一仁,「六自由度飛行軌 道解析による平板状飛散物の飛行性状の検討」, 構 造工学論文集, Vol. 58A, pp. 542-551, (2012)

25) 加茂 正人, 丸山敬, 河井宏允, 西村 宏昭, 「加 撃体として瓦を用いた衝撃試験装置の開発」, 日本 風工学会誌, Vol. 36, No. 2, pp. 117-118, (2011)

26) 加茂 正人, 丸山 敬, 河井宏允, 西村 宏昭, 「瓦を 用いたガラスの耐衝撃試験 その 1 試験装置」, 建 築学会年次大会梗概集, B-1, 構造 I, pp. 19-20, (2011) 
27) 丸山敬, 加茂 正人, 河井宏允, 西村 宏昭, 「瓦 を用いたガラスの耐衝撃試験 その 2 試験結果と 標準加撃体の提案」, 建築学会年次大会梗概集, 構 造 I, pp. 21-22, (2011) 